\title{
Physiological and Biochemical Basis of Water-Deficit Stress Tolerance in Pearl Millet Hybrid and Parents
}

\author{
T. Vijayalakshmi, Y. Varalaxmi, S. Jainender, S. K. Yadav, M. Vanaja, N. Jyothilakshmi, M. Maheswari
}

Division of Crop Sciences, Central Research Institute for Dryland Agriculture, Hyderabad, India.

Email: mmandapaka59@gmail.com

Received September $14^{\text {th }}, 2012$; revised October $20^{\text {th }}, 2012$; accepted November $20^{\text {th }}, 2012$

\begin{abstract}
The present investigation was aimed to understand the physiological and biochemical basis of water-deficit stress tolerance in pearl millet [Pennisetum glaucum (L.) R. Br.] hybrid ICMH 356 and its parents ICMR $356(\widehat{\delta})$ and ICMB $88004\left(\begin{array}{l}(+) \\ )\end{array}\right)$ in response to and recovery from drought stress and also to comprehend crop adaptation under dryland conditions. A field experiment was conducted in a split plot design with moisture levels as the main plot and genotypes as the sub plots. A comparative analysis of hybrid and parents under well-watered and water-deficit stress conditions revealed that the hybrid was superior over the parents in terms of leaf water relations, excised leaf water retention capacity, accumulation of compatible solutes, photosynthesis, membrane stability index and antioxidative enzyme viz., superoxide dismutase (SOD), catalase (CAT), glutathione reductase (GR), ascorbate peroxidase (APX) and guaiacol peroxidase (GPOX) activities. ANOVA for these parameters was also found to be significant for genotypes, treatments and their interactions at $0.01 \%$ level. Maintenance of superiority in terms of these physiological and biochemical parameters coupled with better recovery ability upon stress relief are crucial physiological mechanisms contributing to water deficit stress tolerance in pearl millet. Simple correlation coefficient analysis revealed significant positive association of yield at $0.01 \%$ level with relative water content, leaf water potential, stomatal conductance, photosynthesis, proline, total soluble sugars, free amino acids, membrane stability index, leaf area index and total biomass, while a significant negative association with solute potential and malondialdehyde content, under water-deficit stress clearly indicated that such relationships can be positively attributed to drought tolerance.
\end{abstract}

Keywords: Pearl Millet; Water Relations; Osmotic Adjustment; Membrane Stability Index; Antioxidative Enzymes; Seed Yield

\section{Introduction}

Abiotic stresses such as extreme temperatures, low water availability, flooding and high salt levels are the major limiting factors for plant growth and productivity. The recent trends in global climate change and increasing erratic weather patterns are likely to aggravate these further. Drought is one of the most important abiotic stresses limiting global crop production. In order to combat its adverse effects, it is essential to develop water-deficit stress tolerant genotypes. To achieve that, a better understanding of the stress induced responses and the interrelationships of physiological and biochemical traits in drought tolerant crop such as pearl millet can prove to be very useful.

It has been recognized that plants exhibit several adaptations to survive under stress conditions. Reduced leaf area, stomatal closure to prevent the transpirational water loss, decreased stomatal conductance, limited internal $\mathrm{CO}_{2}$ concentration, reduced photosynthesis are very vital
[1]. These responses in turn trigger the cellular responses viz., diminished leaf water potential, loss of turgor, changes in solute concentration and osmotic adjustment [2]. Osmotic adjustment (OA) is an important mechanism which alleviates some of the detrimental effects of water stress due to the accumulation of osmolytes like proline, TSS and FAA. Apart from their role in OA, they play a role in reactive oxygen species (ROS) signaling [3]. Water-deficit stress tolerance is thus the result of coordination of physiological and biochemical alterations at the organ, cellular and molecular levels [4].

ROS are produced continuously as byproducts of various metabolic pathways in different cellular compartments. However, ROS generation is increased under stress condition which is highly toxic to the plant cell. In order to cope with continuous ROS production under water-deficit stress, plants have a battery of antioxidative enzymes that function as an extremely efficient cooperative system. The major scavenging mechanisms include superoxide dismutase (SOD), catalase (CAT), glutathi- 
one reductase (GR), ascorbate peroxidase (APX) and guaiacol peroxidase (GPOX) [5]. SOD is the front-line enzyme in ROS attack, since it rapidly scavenges superoxide, dismutating it to oxygen and $\mathrm{H}_{2} \mathrm{O}_{2}$ which in turn activates downstream antioxidative enzymes there by scavenging ROS [6]. Although these physiological and biochemical mechanisms of stress response are common to all the plants, major differences exist in terms of strategies adapted by different crop species to cope with drought stress [7].

Pearl millet is an important cereal crop which can withstand drought and is best suited for arid and semiarid regions. It has been cultivated mostly due to its importance as food and fodder. Pearl millet in near future may extend into regions that are too dry for sorghum due to its exceptional ability to tolerate drought [8]. Therefore, various traits associated with drought tolerance need to be evaluated extensively for understanding the mechanism of drought tolerance. Though pearl millet is affected by drought at different stages of crop growth but principal decline in yield occurs when it coincides with reproductive stage. Whan et al. [9] reported that the most important drought resistant mechanism is resistance to post-anthesis drought stress since the products produced during this period are transported into the grain. As stress occurrence at post-anthesis stage is vital cause for yield reduction, it would be more appropriate to study stress responses at this stage. The present study was aimed to assess the effect of water-deficit stress and its relief on different physiological and biochemical processes along with the assay of antioxidative enzymes to ascertain their role in stress tolerance.

\section{Materials and Methods}

\subsection{Plant Material and Experimental Details}

A field experiment was conducted at crossing block complex of Central Research Institute for Dryland Agriculture (CRIDA), located between $17.20^{\circ} \mathrm{N}$ latitude and $78.30^{\circ} \mathrm{E}$ longitude, Hyderabad, AP (India) with pearl millet hybrid ICMH 356 and its inbred parents ICMR $356\left({ }^{\AA}\right)$ and ICMB 88004 (우). The experimental design was split plot with moisture levels as the main plot and genotypes as the sub plots with three replications. The main plot size was $7 \times 13 \mathrm{~m}$. Each main plot was delimited into nine subplots of $2 \mathrm{~m}$ each with $0.5 \mathrm{~m}$ path between them. The sub-plot size was $2 \times 1.5 \mathrm{~m}$. Each subplot had five rows. The inter row plant spacing was 40 $\mathrm{cm}$ (Figure 1). A fertilizer application of N:P:K at a rate of 20:40:60 kg/ha was applied at sowing and an additional top dressing of $30 \mathrm{~kg} \mathrm{~N} / \mathrm{ha}$ was applied one month after planting. Total rainfall received during the crop growth period was $504 \mathrm{~mm}$ with an average maximum and minimum air temperature of $33.6^{\circ} \mathrm{C}$ and $20.5^{\circ} \mathrm{C}$

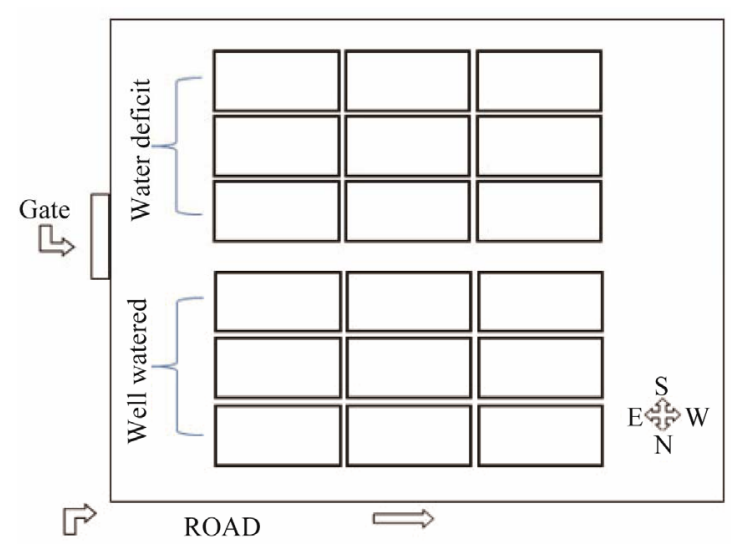

Figure 1. Layout of the experimental field.

respectively.

Two moisture levels were maintained 1) well-watered (WW) control treatment in which plants were irrigated at regular intervals in order to maintain the plants in stress free condition, and 2) water-deficit stress treatment (WDS) in which plants were maintained stress free only till they reached early vegetative stage (35 days after sowing) and subsequently raised purely on rainfall. A dry spell of 10 days occurred from 53 to 63 days after sowing corresponding with the post anthesis stage of crop growth period. Soil moisture recorded during stress period in WW and WDS plots was $14 \%$ and 5\% respectively. In all the genotypes, physiological observations were recorded during stress and one week after stress relief (71DAS) in both WW and WDS treatments.

\subsection{Water Relations, Excised Leaf Water Retention Capacity, Compatible Solutes and Osmotic Adjustment}

Plant water stress was quantified in the flag leaf by measuring relative water content (RWC) [10], leaf water potential $\left(\Psi_{1}\right)$ (Soil Moisture Equipments Corp., USA) and solute potential ( $\Psi \mathrm{s})$ (Vapour Pressure OsmometerModel 5500 Wescor Inc., USA [11]. Osmotic adjustment was calculated from the measured values of solute potential and relative water content [12]. The $\mathrm{OP}_{100}$ was calculated as:

$$
\mathrm{OP}_{100}=\mathrm{OP}[(\mathrm{RWC}-\mathrm{B}) /(100-\mathrm{B})]
$$

where RWC is relative water content and B is apoplastic water. A constant B value of 20 percent was used for both WW and WDS treatments, since B did not change with genotype or dehydration [13]. Excised leaf water retention capacity (ELWRC) curves were drawn to record the moisture percent actually retained by the leaf when it was excised from the plant [14]. Accumulation of proline [15], total soluble sugars (TSS) [16] and free amino acids (FAA) [17] were estimated in the cell sap 
collected from the leaves of WW and WDS plants.

\subsection{Stomatal Conductance, Transpiration, Photosynthesis, Leaf Temperature and Canopy Temperature}

The rate of stomatal conductance $\left(\mathrm{g}_{\mathrm{s}}\right)$, transpiration $\left(\mathrm{T}_{\mathrm{r}}\right)$, photosynthesis $\left(\mathrm{P}_{\mathrm{n}}\right)$ and leaf temperature (LT) were measured in the flag leaves of WW and WDS treatments between 1000 and $1100 \mathrm{~h}$ by using LI-6400 portable photosynthesis system (LI-COR, Inc. Lincoln, USA). Canopy temperature (CT) was recorded with infrared thermometer (Instatherm, Barnes Company, Connecticut, USA) [18].

\subsection{Lipid Peroxidation and Membrane Stability Index}

During stress, the level of lipid peroxidation (LP) was measured in terms of malondialdehyde (MDA) content [19]. The absorbance of MDA content was recorded at $532 \mathrm{~nm}$ and the non-specific absorption at $600 \mathrm{~nm}$ was subtracted. The MDA content was calculated using its absorption coefficient of $155 \mathrm{mM} / \mathrm{cm}$ and expressed as $\mu \mathrm{mol} / \mathrm{g}$ dry weight. Leaf membrane stability index (MSI) was recorded using conductivity bridge [20] as modified by Sairam [21]. MSI was calculated using the following formula.

$$
\mathrm{MSI}=[1-(\mathrm{C} 1 / \mathrm{C} 2)] \times 100
$$

where, $\mathrm{C} 1$ and $\mathrm{C} 2$ are the electric conductivities recorded at $40^{\circ} \mathrm{C}$ and $100^{\circ} \mathrm{C}$ respectively.

\subsection{In Vitro Assay of Antioxidative Enzymes}

In vitro assay of antioxidative enzymes viz., SOD, CAT, GR, APX and GPOX was carried out during stress in WW and WDS plants. The leaf tissue was homogenized in $100 \mathrm{mM}$ potassium phosphate buffer $(\mathrm{pH}$ 7.5) containing $0.5 \mathrm{mM}$ EDTA. The homogenate was centrifuged at $10,000 \mathrm{rpm}$ for $20 \mathrm{~min}$ at $4^{\circ} \mathrm{C}$ and the supernatant was used for the determination of enzyme activity. Enzyme extract for the determination of APX was performed as described above, except that the homogenization buffer also contained $5 \mathrm{mM}$ ascorbate. Soluble protein content in the enzyme extract was determined using bovine serum albumin as standard [22]. Total activities of all the antioxidative enzymes were monitored using kinetics for a period of $3 \mathrm{~min}$ in the spectrophotometer and expressed as enzyme units $/ \mathrm{mg}$ protein $/ \mathrm{min}$.

SOD activity was assayed by recording the enzyme induced decrease in absorbance of formazone made by nitro-blue tetrazolium chloride with superoxide radicals [23]. The reaction mixture contained $13 \mathrm{mM}$ methionine, $25 \mathrm{mM}$ nitro-blue tetrazolium chloride (NBT), $0.1 \mathrm{mM}$ EDTA, $50 \mathrm{mM}$ phosphate buffer $(\mathrm{pH} 7.8)$ and $50 \mathrm{mM}$ sodium carbonate. Two tubes without enzyme extract were maintained as controls, while one of them was nonirradiated and the other was irradiated. Reaction was started by adding $2 \mu \mathrm{M}$ riboflavin and the tubes were placed below the light source of two $15 \mathrm{~W}$ fluorescent lamps for $15 \mathrm{~min}$. Reaction was stopped by placing the tubes in dark. Tubes without enzyme developed maximum colour which served as control. A non-irradiated complete reaction mixture that did not develop colour served as blank. Absorbance was recorded at $560 \mathrm{~nm}$ and one unit of enzyme activity was taken as the quantity of enzyme, which reduced the absorbance reading of samples to $50 \%$ in comparison with tubes lacking the enzyme. Catalase activity was assayed from the rate of $\mathrm{H}_{2} \mathrm{O}_{2}$ decomposition as measured by the decrease of absorbance at $240 \mathrm{~nm}$ [24]. The reaction mixture consisted of 0.059 $\mathrm{M} \mathrm{H}_{2} \mathrm{O}_{2}$ in $0.1 \mathrm{M}$ potassium phosphate buffer ( $\mathrm{pH}$ 7.0). One unit is defined as the amount of enzyme that decomposes $1 \mu \mathrm{mol}$ of $\mathrm{H}_{2} \mathrm{O}_{2}$ per min at $25^{\circ} \mathrm{C}$ and $\mathrm{pH}$ 7.0. GR activity was estimated by recording the increase in absorbance in the presence of oxidized glutathione and DTNB (5,5-dithibis-2-nitrobenzoic acid) [25]. The reaction mixture consisted of $6.67 \mathrm{mM}$ potassium phosphate buffer ( $\mathrm{pH} 7.5$ ) containing $33.33 \mu \mathrm{M}$ EDTA, $0.5 \mathrm{mM}$ DTNB, $66.67 \mu \mathrm{M} \mathrm{NADPH}$ and the reaction was initiated by adding $66.67 \mu \mathrm{M}$ GSSG (oxidized glutathione). One unit will cause the oxidation of $1.0 \mu \mathrm{mol}$ of NADPH at $\mathrm{pH}$ 7.5. APX activity was assayed from the rate of $\mathrm{H}_{2} \mathrm{O}_{2}$ decomposition as measured by the decrease in absorbance at $290 \mathrm{~nm}$ [26]. The reaction mixture contained 50 $\mathrm{mM}$ potassium phosphate buffer ( $\mathrm{pH} 7.5), 0.5 \mathrm{mM}$ ascorbic acid, $0.1 \mathrm{mM}$ EDTA and the reaction was started with the addition of $0.1 \mathrm{mM} \mathrm{H} \mathrm{H}_{2}$. GPOX activity was determined by the increase in absorbance at $470 \mathrm{~nm}$ [27]. The reaction mixture contained $50 \mathrm{mM}$ potassium phosphate buffer ( $\mathrm{pH} 6.9$ ), $3.2 \mathrm{mM}$ guaiacol and $0.4 \mathrm{mM}$ $\mathrm{H}_{2} \mathrm{O}_{2}$. One unit is the amount of enzyme which catalyses the conversion of $1 \mu \mathrm{mol}$ of $\mathrm{H}_{2} \mathrm{O}_{2}$ per minute at $25^{\circ} \mathrm{C} \pm$ $2^{\circ} \mathrm{C}$. For each of the enzyme activities, $50 \mu \mathrm{l}$ of enzyme extract and distilled water was added to a final volume of $3 \mathrm{ml}$. Except for SOD, the absorbance was recorded at regular intervals of $30 \mathrm{~s}$ over a period of $3 \mathrm{~min}$ in a spectrophotometer.

\subsection{Leaf Area Index, Total Biomass and Seed Yield}

Leaf area was recorded using leaf area meter (Li-COR 3100, Li-COR Inc., USA) and leaf area index (LAI) was calculated. Leaf area, total biomass and seed yield of all the genotypes were calculated by harvesting plants from $0.5 \mathrm{~m}$ area from each of the three replicates.

\subsection{Statistical Analysis}

Analysis of variance (ANOVA) with three replications 
per treatment (WW and WDS), three genotypes (hybrid and its parents) and interaction between treatments and genotypes was carried out for the individual physiological and biochemical traits [28]. Correlation coefficient analysis was performed to study the interrelationships between different traits using xlstat.

\section{Results and Discussion}

The present study was aimed to understand the physiological and biochemical basis of WDS tolerance in pearl millet hybrid and parents. The ability to withstand WDS was studied in terms of water relations, photosynthesis, MSI, accumulation of compatible solutes and activity of AOX enzymes. A comparative analysis of the hybrid and parents under WDS revealed that the hybrid was superior over the parents in terms of leaf water relations, OA, ELWRC, $\mathrm{g}_{\mathrm{s}}, \mathrm{T}_{\mathrm{r}}, \mathrm{P}_{\mathrm{n}}, \mathrm{LT}, \mathrm{CT}$, LAI, TB, accumulation of compatible solutes and AOX enzyme activity.

Data recorded on monthly mean, maximum and minimum temperatures, relative humidity, rainfall and at least 7 days rainless period frequency during the growth period of pearl millet genotypes are presented in Table $\mathbf{1}$. The total rainfall recorded during the crop growth period was $504 \mathrm{~mm}$. Three rainless periods occurred during vegetative stage and one occurred at post anthesis stage. Since post anthesis stage is very important for yield reduction, the performance of pearl millet hybrid and parents was analyzed at this stage using various physiological and biochemical parameters.

\subsection{Water Relations, Excised Leaf Water Retention Capacity, Compatible Solutes and Osmotic Adjustment}

WDS caused a sharp decline in RWC, $\Psi_{1}$ and $\Psi_{\mathrm{s}}$ leading to lower plant water status in pearl millet genotypes (Figure 2). Under WDS, the hybrid maintained higher (86.3\%) RWC suggesting its relatively higher ability to avoid tissue dehydration. The decrease in $\Psi_{1}$ was concomitant to the decrease in $\Psi_{\mathrm{s}}$. The decrease in $\Psi_{\mathrm{s}}(80 \%)$ was more compared to the $\Psi_{1}(41 \%)$ indicating the ability of the leaves to maintain turgor through OA. Henson et al. [29], also showed that OA is a criterion of selection for characterizing the drought tolerant varieties of durum. ELWRC assessed also showed significant differences in water holding capacity of excised leaves in pearl millet hybrid and its parents. The hybrid retained higher ELWRC (74\%) when compared with its parental lines (Figure 3). The maintenance of quick stomatal response to excision, coupled with lower radiation load due to higher reflectivity and transmittance in the infrared region [14] in the hybrid could have enabled the excised leaves to retain moisture for longer periods. ELWRC was earlier shown to be associated with some of the key plant characters which have a great bearing on seed yield [30]. Hence, ELWRC can be used for screening drought tolerance in pearl millet.

Analysis of compatible solutes under WDS revealed that accumulation of proline (2.8 folds) was comparatively more than TSS and FAA (1.8 folds) in the hybrid as compared to its parents (Figure 4). The results of ANOVA for RWC, $\Psi_{1}, \Psi_{\mathrm{s}}$, proline, TSS and FAA were found to be significant for genotypes, treatments and their interactions at $0.01 \%$ level (Table 2). Accumulation of compatible solutes is known to impart water-deficit stress tolerance through active reduction in $\Psi_{\mathrm{s}}$. It is important to note that hybrid showing higher level of proline accumulation was least affected by the oxidative stress attributing an antioxidant feature to proline [3]. The active reduction in $\Psi_{\mathrm{s}}$ through accumulation of compatible solutes is known to manifest as OA as demonstrated in a wide range of species including dryland crops such as sorghum [31] and pearl millet [32]. The hybrid and male parent showed higher OA (1.0 MPa) while the female parent showed comparatively lower OA $(0.45$ $\mathrm{MPa}$ ) (Figure 5). Thus, it appears that OA could have protected the pearl millet hybrid and parents from the deleterious effects of water-deficit stress [33]. After stress relief, the genotypes under stress recovered and reached to the level of WW control plants as indicated by the decrease in the level of compatible solutes. The hybrid recovered better compared to its parents.

Table 1. Mean, minimum and maximum temperature and rainfall recorded during crop growth period (21 June 2007 to 10 October 2007).

\begin{tabular}{|c|c|c|c|c|c|c|}
\hline \multirow{2}{*}{ Month } & \multicolumn{3}{|c|}{ Temperature $\left({ }^{\circ} \mathrm{C}\right)$} & \multirow{2}{*}{ Rainfall (mm) } & \multirow{2}{*}{ No. of rainy days } & \multirow{2}{*}{$\begin{array}{l}\text { At least } 7 \text { days rainless } \\
\text { period frequency }\end{array}$} \\
\hline & Max. & Min. & Mean & & & \\
\hline June & 31.5 & 20.5 & 26.0 & 78.1 & 9 & 0 \\
\hline July & 33.6 & 21.5 & 27.6 & 24.2 & 4 & 3 \\
\hline August & 33.4 & 21.0 & 27.2 & 212.3 & 18 & 1 \\
\hline September & 33.2 & 21.2 & 27.2 & 174.4 & 16 & 0 \\
\hline October & 32.0 & 21.5 & 26.8 & 15.0 & 4 & 0 \\
\hline
\end{tabular}




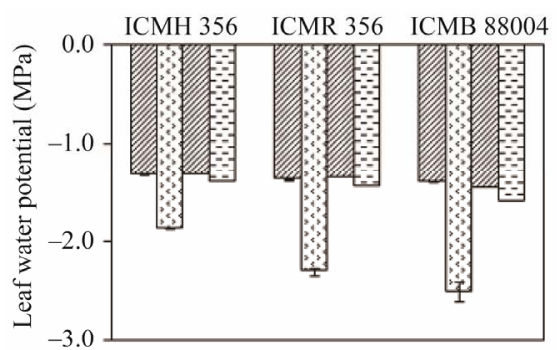

(a)

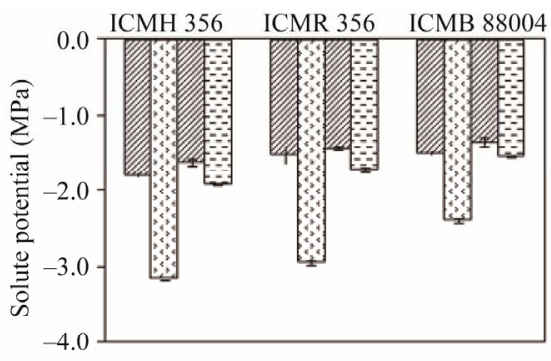

(b)

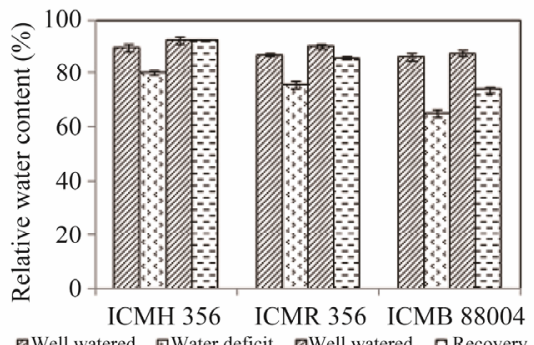

(c)

Figure 2. Effect of water-deficit stress and its relief on (a) Leaf water potential; (b) Solute potential; (c) Relative water content in the leaves of pearl millet hybrid and parents.

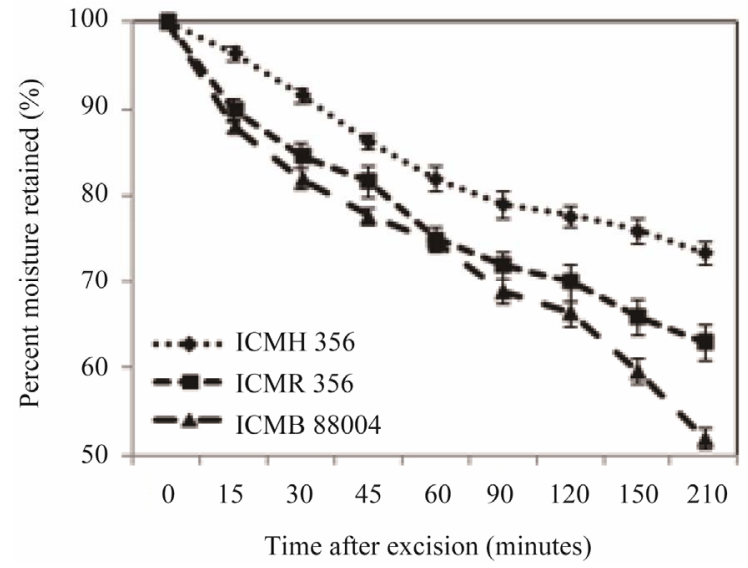

Figure 3. Excised leaf water retention capacity in pearl millet hybrid and parents.

\subsection{Lipid Peroxidation, Membrane Stability Index and in Vitro Assay of Antioxidative Enzymes}

It is widely accepted that WDS induced ROS are responsible for various stress-induced damages to macromolecules mainly lipid membrane peroxidation and electrolyte leakage [34] which can be determined by measuring MDA content and MSI. In the present study, the hybrid maintained relatively better membrane stability than the parents which is indicated by lower MDA (37\%) content and higher MSI (85\%) (Figure 6). LP is used as an index of oxidative damages caused by various environmental stresses in plants. Such that ROS reacts with lipids and leads to the formation of highly active peroxyl radical, (a)

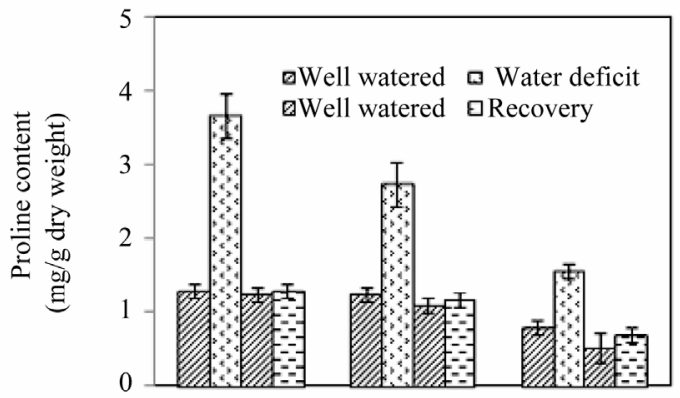

(b)

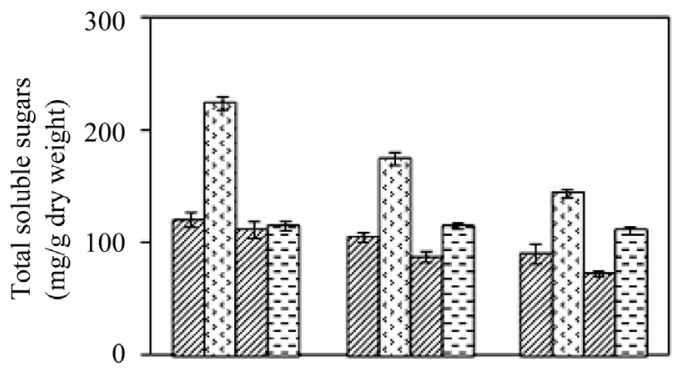

(c)

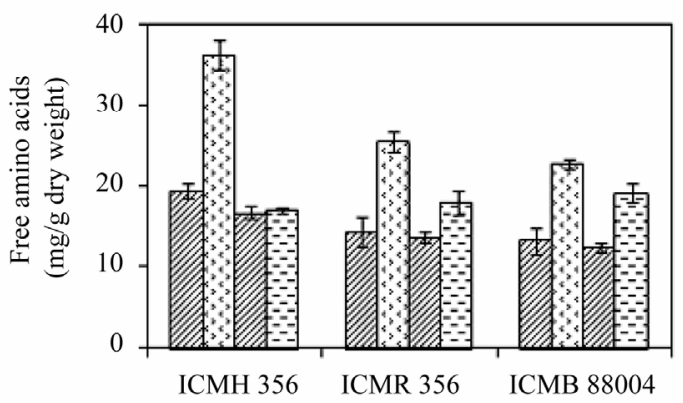

Figure 4. Effect of water-deficit stress and its relief on (a) Accumulation of proline; (b) Total soluble sugars and (c) Free amino acids in pearl millet hybrid and parents. 
Table 2. Analysis of variance for different physiological and biochemical parameters in pearl millet hybrid and parents.

\begin{tabular}{|c|c|c|c|c|}
\hline \multicolumn{5}{|c|}{ Mean sum of squares } \\
\hline Parameter & Genotypes (G) df(2) & Treatments (T) df(3) & $G \times T d f(6)$ & Error df(22) \\
\hline Relative water content & $329.7^{* *}$ & $464.7^{* *}$ & $45.3^{* *}$ & 3.4 \\
\hline Leaf water potential & $0.202^{* *}$ & $1.525^{* *}$ & $0.054^{* *}$ & 0.004 \\
\hline Solute potential & $0.115^{* *}$ & $4.723^{* *}$ & $0.169^{* *}$ & 0.006 \\
\hline Proline & $3.02^{* *}$ & $5.95^{* *}$ & $0.42^{* *}$ & 0.03 \\
\hline Total soluble sugars & $3672^{* *}$ & $14618^{* *}$ & $949^{* *}$ & 83 \\
\hline Free amino acids & $100^{* *}$ & $352^{* *}$ & $34^{* *}$ & 3.8 \\
\hline Stomatal conductance & $0.066^{* *}$ & $0.118^{* *}$ & 0.001 & 0.002 \\
\hline Photosynthesis & $370.3^{* *}$ & $482.1^{* *}$ & $12.8^{* *}$ & 3.3 \\
\hline Transpiration & 9 & $17.9^{* *}$ & 0.2 & 0.2 \\
\hline Canopy temperature & $9.5^{* *}$ & $8.4^{* *}$ & 0.3 & 0.3 \\
\hline Leaf temperature & $2.82^{* *}$ & $1.43^{*}$ & 0.05 & 0.44 \\
\hline Leaf area index & $0.139^{* *}$ & $0.045^{* *}$ & 0.006 & 0.005 \\
\hline
\end{tabular}

* and ${ }^{* *}$ significant at $0.05 \%$ and $0.01 \%$ level, $d f$ degrees of freedom.

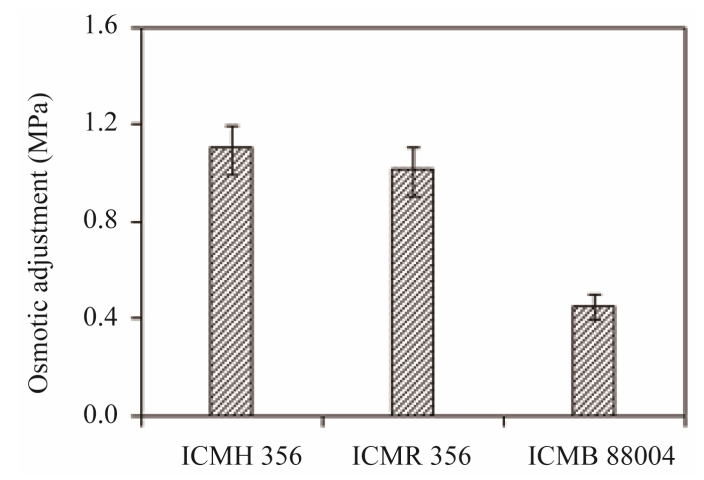

Figure 5. Osmotic adjustment in pearl millet hybrid and parents.

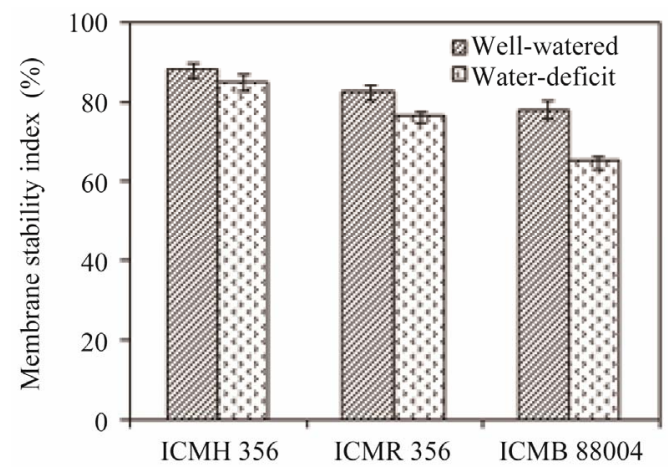

Figure 6. Membrane stability index in pearl millet hybrid and parents.

which in turn starts chain propagation reaction of lipid peroxidation [34]. Hence, LP and MSI can be used as indicators of stress-induced damages at the cellular level in pearl millet.

The ROS scavenging ability of the crop plant partly relies on the induction of different enzymes of the antioxidative pathway which is initiated by the induction of SOD activity and subsequent up regulation of other downstream antioxidative enzymes [35]. In the present study, WDS caused an increase in the levels of AOX enzymes such as SOD, CAT, GR, APX and GPOX (Figure 7). ANOVA for LP, MDA, SOD, CAT, GR, APX and GPOX were found to be significant for genotypes, treatments and their interactions at $0.01 \%$ level (Table 3). Enhanced AOX enzyme activities under WDS stress was also reported earlier in pearl millet hybrids [36]. Among the different AOX enzymes, GR known to scavenge singlet oxygen, superoxide and hydroxyl radicals and APX that function as a fine regulator of intracellular ROS levels [5] were observed to be highly induced in the hybrid when compared to its parents. Lower MDA content, higher MSI coupled with enhanced activity of AOX enzymes in the hybrid resulted in reducing the negative impact of ROS on membrane damage indicating the presence of an efficient antioxidative mechanism in the hybrid.

\subsection{Stomatal Conductance, Transpiration, Photosynthesis, Leaf Temperature and Canopy Temperature}

It is well documented that one of the first responses of plants to drought is stomatal closure to avoid excessive water loss through transpiration and to protect the photosynthetic machinery. Therefore, the effect of waterdeficit stress on gs, $\mathrm{T}_{\mathrm{r}}$ and $\mathrm{P}_{\mathrm{n}}$ were monitored. Under WDS, $g_{s}, T_{r}$ and $P_{n}$ were decreased in both hybrid and parental lines of pearl millet (Figure 8). Lower $\Psi_{1}$ and stomatal closure caused a decrease in $\mathrm{P}_{\mathrm{n}}$ rate resulting in decreased $\mathrm{CO}_{2}$ availability and rubisco activity as was also reported by Tezara et al. [37]. The increase in leaf temperature and canopy temperature was significantly lower $\left(2^{\circ} \mathrm{C}-3^{\circ} \mathrm{C}\right)$ in the hybrid as compared to its parents. The capacity of hybrids to maintain higher $\mathrm{T}_{\mathrm{r}}$ rates under both WW as well as WDS conditions probably helped to maintain cooler leaf and canopy temperatures. After stress relief, the hybrid and male parent recovered better 
Table 3. Analysis of variance for membrane stability index, malondialdehyde, superoxide dismutase, catalase, glutathione reductase, ascorbate peroxidase and guaiacol peroxidase in pearl millet hybrid and parents.

\begin{tabular}{ccccccccc}
\hline & \multicolumn{9}{c}{ Mean sum of squares } \\
\hline Source of variation & $d f$ & MSI & MDA & SOD & CAT & GR & APX & GPOX \\
\hline Genotypes (G) & 2 & $360^{* *}$ & $507^{* *}$ & $73^{* *}$ & $30^{* *}$ & $40^{* *}$ & $260^{* *}$ & $1661^{* *}$ \\
Treatments (T) & 1 & $234^{* *}$ & $621^{* *}$ & $50^{* *}$ & $69^{* *}$ & $104^{* *}$ & $4446^{* *}$ & $3618^{* *}$ \\
G $\times$ T & 2 & 41 & $80^{* *}$ & 11 & $4^{*}$ & $16^{* *}$ & $246^{* *}$ & $470^{* *}$ \\
Error & 10 & 13 & 4 & 4.3 & 0.6 & 1 & 9 & 5 \\
\hline
\end{tabular}

${ }^{*}$ and ${ }^{* *}$ significant at $0.05 \%$ and $0.01 \%$ level, $d f$ : degrees of freedom.

(a)

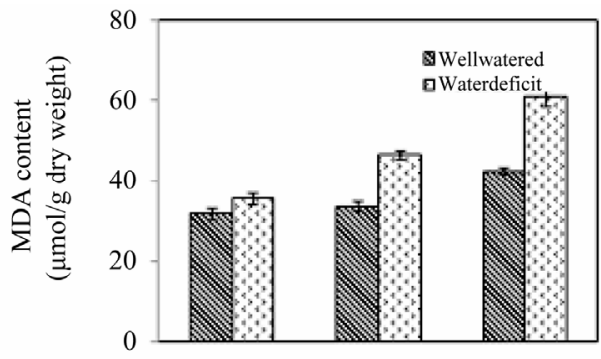

(b)

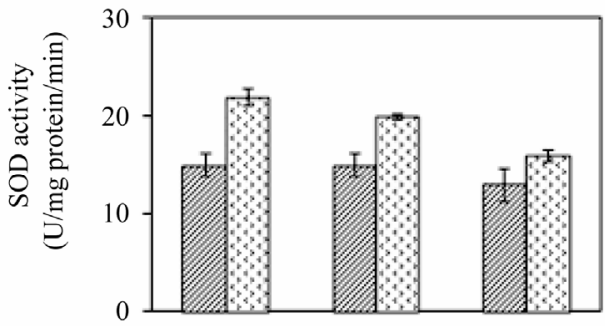

(c)

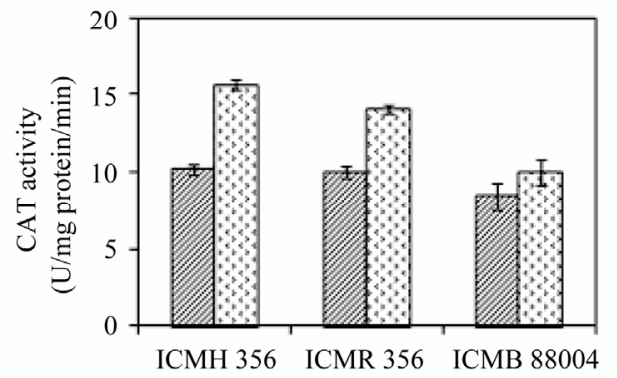

(d)

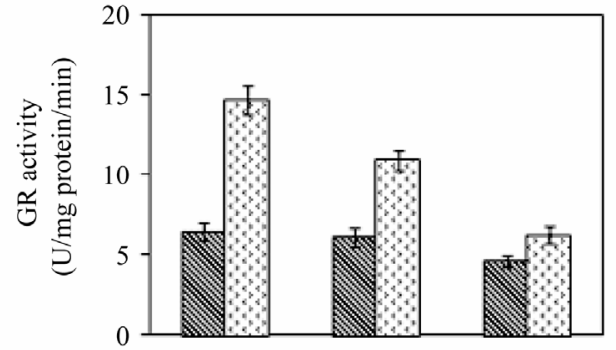

(e)

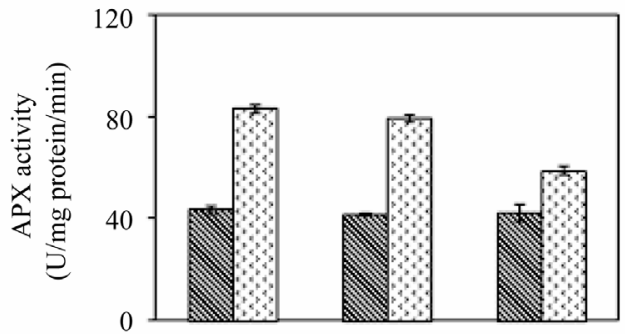

(f)

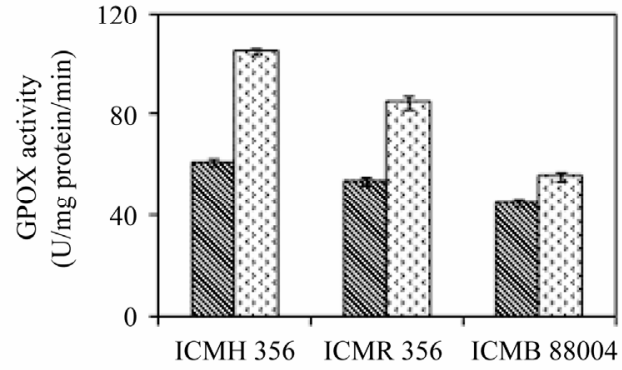

Figure 7. Effect of water-deficit stress on (a) Malondialdehyde content; (b) Superoxide dismutase(SOD); (c) Catalase (CAT); (d) Glutathione reductase(GR); (e) Ascorbate peroxidase (APX); (f) Guaiacol peroxidase (GPOX).

and were at par with each other in terms of gs $(96 \%), \mathrm{T}_{\mathrm{r}}$ $(96 \%)$ and $P_{n}(92 \%)$ and reached to the level of the WW control while, the recovery in female parent was lower in gs $(71 \%), \mathrm{T}_{\mathrm{r}}(77 \%)$ and $\mathrm{P}_{\mathrm{n}}(46.5 \%)$. Maintenance of $\mathrm{g}_{\mathrm{s}}$, $\mathrm{T}_{\mathrm{r}}$ and $\mathrm{P}_{\mathrm{n}}$ coupled with better recovery of the hybrid indicated the ability of the hybrid to protect its photosynthetic machinery against the stress-induced damages.

\subsection{Leaf Area Index, Total Biomass and Seed Yield}

Even under WDS, the hybrid maintained relatively higher LAI (Figure 8) as compared to its parents resulting in higher dry matter accumulation and ultimately the yield. Maintenance of higher LAI seems to be an important factor leading to a greater realization of sink potential which is in agreement with the findings of KhannaChopra and Maheswari [38] in maize hybrid and parents. The results of ANOVA for $\mathrm{g}_{\mathrm{s}}, \mathrm{T}_{\mathrm{r}}, \mathrm{P}_{\mathrm{n}}, \mathrm{LT}, \mathrm{CT}$ and LAI were found to be significant for genotypes, treatments and their interaction between genotypes and treatments were non significant for $\mathrm{g}_{\mathrm{s}}, \mathrm{T}_{\mathrm{r}}, \mathrm{P}_{\mathrm{n}}, \mathrm{LT}, \mathrm{CT}$ and LAI.

WDS resulted in remarkable reduction in TB $(3.2 \%$ $13.5 \%)$ and yield $(14 \%-57.7 \%)$ in pearl millet hybrid and its parents compared to that under WW conditions (Table 4). The hybrid showed higher yield in comparison to its parents, which resulted due to the maintenance of higher RWC and $\Psi_{1}$. Thus, the maintenance of high $\Psi_{1}$ probably minimized the adverse effects of WDS on 
(a)

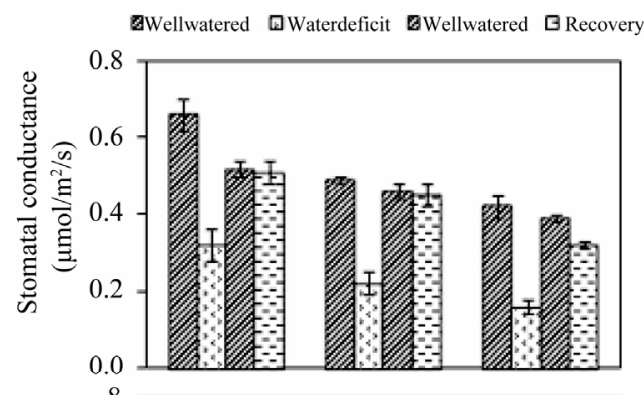

(b)

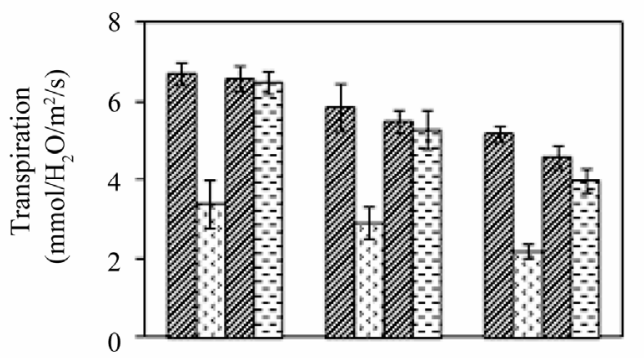

(c)

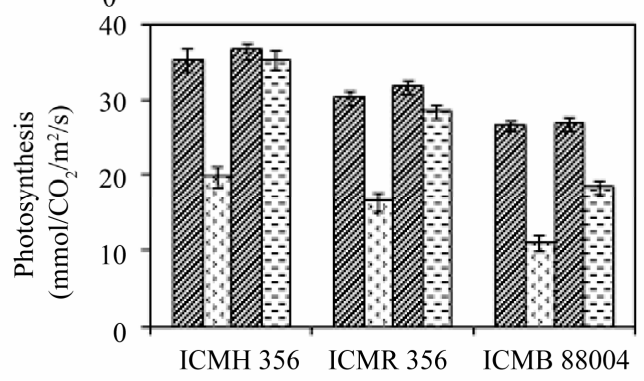

(d)

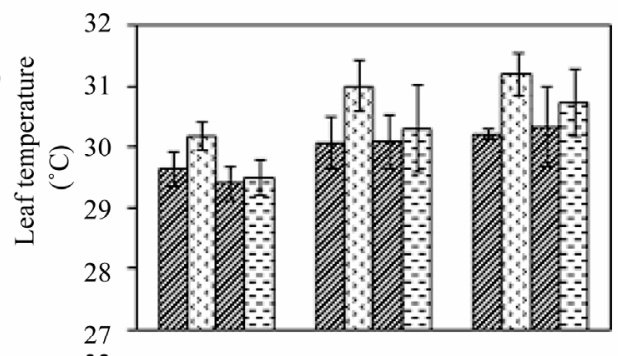

(e)

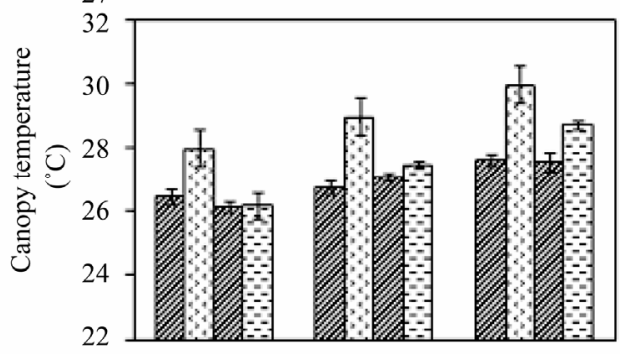

(f)

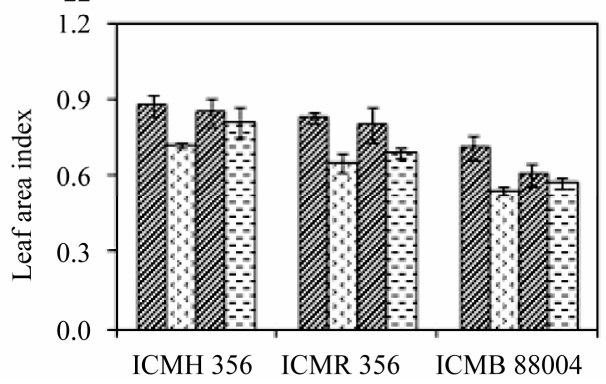

Figure 8. Effect of water-deficit stress and its relief on (a) Stomatal conductance; (b) Transpiration; (c) Photosynthesis; (d) Leaf temperature; (e) Canopy temperature; (f) Leaf area index in pearl millet hybrid and parents.

Table 4. Effect of water-deficit stress on total biomass and grain yield in pearl millet hybrid and parents under field conditions.

\begin{tabular}{cccc}
\hline Genotypes & Treatment & Total biomass $\left(\mathrm{g} / \mathrm{m}^{2}\right)$ & Grain yield $\left(\mathrm{g} / \mathrm{m}^{2}\right)$ \\
\hline ICMH 356 & WW & 457 & 325 \\
& WDS & 442 & 278 \\
ICMR 356 & WW & 427 & 273 \\
& WDS & 381 & 201 \\
ICMB 88004 & WW & 386 & 244 \\
& WDS & 333 & 103 \\
CD at $0.05 \%$ & Genotype & 12.0 & 30.2 \\
& Treatment & 9.8 & 24.6 \\
\end{tabular}

growth, biomass and yield. The results of ANOVA for TB and yield were also found to be significant for genotypes, treatments and their interactions at $0.01 \%$ level. The decrease in TB under stress could be due to reduced $\mathrm{P}_{\mathrm{n}}$ and LAI. In wheat, the primary cause of reduced biomass production was found to be associated with decrease in the radiation use efficiency [39].

\subsection{Simple Correlation Coefficient Analysis}

Simple correlation coefficient analysis among the various physiological and biochemical parameters in pearl millet under WW conditions revealed a significant positive association $(0.01 \%$ level $)$ of yield with $\mathrm{CT}, \mathrm{T}_{\mathrm{r}}, \mathrm{P}_{\mathrm{n}}, \Psi_{1}$ and TB. Under WDS, yield was significantly and positively $\left(0.01 \%\right.$ level) associated with LAI, $\mathrm{g}_{\mathrm{s}}, \mathrm{P}_{\mathrm{n}}, \mathrm{RWC}, \Psi_{1}$, proline, TSS, FAA, MSI and TB. While, $\Psi_{\mathrm{s}}$ and MDA were significantly and negatively correlated with yield (Tables 5(a) and (b)). This analysis clearly brings out that maintenance of higher leaf area, photosynthetic machinery, plant water status, accumulation of compatible solutes 
Table 5. (a) Simple correlation coefficient among different physiological and biochemical parameters in pearl millet under (a) well-watered; (b) water-deficit stress.

(a)

\begin{tabular}{|c|c|c|c|c|c|c|c|c|c|c|c|c|c|c|c|c|}
\hline Variables & LAI & LT & $\mathrm{CT}$ & $\mathrm{g}_{\mathrm{s}}$ & $\mathrm{T}_{\mathrm{r}}$ & $P_{n}$ & RWC & $\Psi_{1}$ & $\Psi_{\mathrm{s}}$ & Proline & TSS & FAA & MDA & MSI & $\mathrm{TB}$ & Yield \\
\hline LAI & 1 & -0.146 & -0.588 & 0.662 & 0.556 & $0.709^{*}$ & $0.676^{*}$ & $0.706^{*}$ & -0.358 & $0.777^{*}$ & $0.881^{* *}$ & $0.748^{*}$ & -0.602 & $0.731^{*}$ & $0.757^{*}$ & $0.745^{*}$ \\
\hline LT & & 1 & 0.124 & -0.484 & -0.074 & -0.434 & -0.223 & -0.377 & 0.447 & -0.258 & -0.329 & -0.452 & 0.409 & -0.535 & -0.469 & -0.365 \\
\hline $\mathrm{CT}$ & & & 1 & -0.265 & $-0.706^{*}$ & $-0.698^{*}$ & -0.448 & $-0.816^{* *}$ & $0.670^{*}$ & $-0.856^{* *}$ & -0.475 & -0.571 & $0.845^{* *}$ & -0.500 & $-0.730^{*}$ & $-0.801^{* *}$ \\
\hline $\mathrm{g}_{\mathrm{s}}$ & & & & 1 & 0.486 & 0.644 & $0.672^{*}$ & 0.548 & -0.285 & 0.600 & 0.654 & 0.409 & -0.596 & 0.645 & $0.801^{* *}$ & 0.625 \\
\hline $\mathrm{T}_{\mathrm{r}}$ & & & & & 1 & 0.457 & $0.843^{* *}$ & $0.681^{*}$ & $-0.688^{*}$ & 0.534 & 0.456 & 0.388 & $-0.768^{*}$ & 0.484 & $0.773^{*}$ & $0.816^{* *}$ \\
\hline$P_{n}$ & & & & & & 1 & 0.532 & $0.925^{* *}$ & -0.615 & $0.848^{* *}$ & $0.776^{*}$ & $0.754^{*}$ & $-0.693^{*}$ & $0.790^{*}$ & $0.820^{* *}$ & $0.813^{* *}$ \\
\hline RWC & & & & & & & 1 & $0.714^{*}$ & $-0.709^{*}$ & 0.421 & $0.731^{*}$ & 0.572 & -0.568 & 0.546 & $0.816^{* *}$ & $0.787^{*}$ \\
\hline$\Psi_{1}$ & & & & & & & & 1 & $-0.839^{* *}$ & $0.793^{*}$ & $0.797^{* *}$ & $0.788^{*}$ & $-0.770^{*}$ & $0.733^{*}$ & $0.891^{* *}$ & $0.902^{* *}$ \\
\hline$\Psi_{\mathrm{s}}$ & & & & & & & & & 1 & -0.433 & -0.550 & -0.654 & 0.620 & -0.460 & $-0.731^{*}$ & $-0.767^{*}$ \\
\hline Proline & & & & & & & & & & 1 & 0.634 & 0.628 & $-0.825^{* *}$ & 0.649 & $0.805^{* *}$ & $0.791^{*}$ \\
\hline TSS & & & & & & & & & & & 1 & $0.780^{*}$ & -0.538 & $0.758^{*}$ & $0.790^{*}$ & $0.675^{*}$ \\
\hline FAA & & & & & & & & & & & & 1 & -0.429 & 0.641 & 0.647 & $0.790^{*}$ \\
\hline MDA & & & & & & & & & & & & & 1 & $-0.695^{*}$ & $-0.881^{* *}$ & $-0.776^{*}$ \\
\hline MSI & & & & & & & & & & & & & & 1 & $0.725^{*}$ & $0.690^{*}$ \\
\hline TB & & & & & & & & & & & & & & & 1 & $0.885^{* *}$ \\
\hline Yield & & & & & & & & & & & & & & & & 1 \\
\hline
\end{tabular}

(b)

\begin{tabular}{|c|c|c|c|c|c|c|c|c|c|c|c|c|c|c|c|c|}
\hline Variables & LAI & LT & CT & $\mathrm{g}_{\mathrm{s}}$ & $\mathrm{T}_{\mathrm{r}}$ & $P_{n}$ & RWC & $\Psi_{1}$ & $\Psi_{\mathrm{s}}$ & Proline & TSS & FAA & MDA & MSI & $\mathrm{TB}$ & Yield \\
\hline LAI & 1 & -0.551 & -0.624 & $4 \quad 0.651$ & 0.426 & $0.692^{*}$ & $0.919^{* *}$ & $0.673^{*}$ & $-0.858^{* *}$ & $0.886^{* *}$ & $0.833^{* *}$ & 0.648 & $-0.857^{*}$ & $0.853^{* *}$ & $0.853^{* *}$ & $0.795^{*}$ \\
\hline LT & & 1 & 0.524 & -0.599 & -0.573 & -0.542 & -0.533 & -0.565 & 0.517 & $-0.704^{*}$ & $-0.763^{*}$ & $-0.682^{*}$ & 0.526 & -0.585 & -0.619 & -0.444 \\
\hline $\mathrm{CT}$ & & & 1 & -0.557 & -0.521 & -0.537 & $-0.678^{*}$ & -0.598 & 0.661 & $-0.789^{*}$ & $-0.753^{*}$ & -0.571 & $0.787^{*}$ & $-0.819^{* *}$ & $-0.698^{*}$ & -0.609 \\
\hline $\mathrm{g}_{\mathrm{s}}$ & & & & 1 & 0.338 & 0.599 & $0.762^{*}$ & $0.908^{* *}$ & $-0.777^{*}$ & $0.707^{*}$ & $0.858^{* *}$ & $0.724^{* *}$ & $-0.798^{* *}$ & $0.779^{*}$ & $0.769^{*}$ & $0.854^{* *}$ \\
\hline $\mathrm{T}_{\mathrm{r}}$ & & & & & 1 & $0.766^{*}$ & 0.517 & 0.554 & -0.602 & $0.752^{*}$ & 0.612 & $0.787^{* *}$ & -0.621 & $0.704^{*}$ & $0.738^{*}$ & 0.601 \\
\hline$P_{n}$ & & & & & & 1 & $0.840^{* *}$ & $0.811^{* *}$ & $-0.908^{* *}$ & $0.865^{* *}$ & $0.830^{* *}$ & $0.868^{* *}$ & $-0.861^{* *}$ & $0.810^{* *}$ & $0.862^{* *}$ & $0.828^{* *}$ \\
\hline RWC & & & & & & & 1 & $0.796^{*}$ & $-0.952^{* *}$ & $0.908^{* *}$ & $0.894^{* *}$ & $0.737^{*}$ & $-0.959^{* *}$ & $0.911^{* *}$ & $0.900^{* *}$ & $0.906^{* *}$ \\
\hline$\Psi_{1}$ & & & & & & & & 1 & $-0.874^{* *}$ & $0.815^{* *}$ & $0.919^{* *}$ & $0.904^{* *}$ & $-0.885^{* *}$ & $0.854^{* *}$ & $0.888^{* *}$ & $0.922^{* *}$ \\
\hline$\Psi_{\mathrm{s}}$ & & & & & & & & & 1 & $-0.921^{* *}$ & $-0.898^{*}$ & $-0.793^{* *}$ & $0.959^{* *}$ & $-0.920^{* *}$ & $-0.909^{* *}$ & ${ }^{*}-0.938^{* *}$ \\
\hline Proline & & & & & & & & & & 1 & $0.941^{* *}$ & $0.860^{* *}$ & $-0.942^{* *}$ & $0.966^{* *}$ & $0.961^{* *}$ & $0.868^{* *}$ \\
\hline TSS & & & & & & & & & & & 1 & $0.900^{* *}$ & $-0.933^{* *}$ & $0.923^{* *}$ & $0.938^{* *}$ & $0.876^{* *}$ \\
\hline FAA & & & & & & & & & & & & 1 & $-0.829^{* *}$ & $0.839^{* *}$ & $0.926^{* *}$ & $0.837^{* *}$ \\
\hline MDA & & & & & & & & & & & & & 1 & $-0.975^{* *}$ & $-0.953^{* *}$ & ${ }^{*}-0.951^{* *}$ \\
\hline MSI & & & & & & & & & & & & & & 1 & $0.969^{* *}$ & $0.934^{* *}$ \\
\hline $\mathrm{TB}$ & & & & & & & & & & & & & & & 1 & $0.941^{* *}$ \\
\hline Yield & & & & & & & & & & & & & & & & 1 \\
\hline
\end{tabular}

${ }^{*}$ and ${ }^{* *}$ significant at $0.05 \%$ and $0.01 \%$ levels respectively. Where, $\mathrm{LAI}=$ leaf area index, $\mathrm{LT}=$ leaf temperature, $\mathrm{CT}=$ canopy temperature, $\mathrm{g}_{\mathrm{s}}=\mathrm{stomatal}$ conductance, $\mathrm{P}_{\mathrm{n}}=$ photosynthesis, $\mathrm{Tr}=$ transpiration, $\mathrm{RWC}=$ relative water content, $\Psi_{1}=$ leaf water potential, $\Psi_{\mathrm{s}}=$ solute potential, TSS=total soluble sugars, FAA $=$ free amino acids, $\mathrm{MDA}=$ malondialdehyde content, $\mathrm{MSI}=$ membrane stability index, $\mathrm{TB}=$ total biomass. 
and MSI play an important role in maintenance of total biomass and grain yield under WDS. Higher leaf area is contributing to a better source capacity which seems to be an important factor leading to a greater realization of sink potential [38]. RWC and MSI are known to be good indicators of stress-induced damages.

\section{Conclusion}

Maintenance of higher plant water relations, ELWRC, proline accumulation, $\mathrm{P}_{\mathrm{n}}$, LAI and TB along with an efficient AOX system coupled with better recovery ability upon stress relief are crucial physiological mechanisms contributing to water deficit stress tolerance in pearl millet. Simple correlation coefficient analysis of different physiological and biochemical parameters also reinforced the finding. Hence, these traits can be used as tools for developing drought tolerant genotypes.

\section{REFERENCES}

[1] M. M. Chaves, J. Flexas and C. Pinheiro, "Photosynthesis under Drought and Salt Stress: Regulation Mechanisms from Whole Plant to Cell," Annals of Botany, Vol. 103, No. 4, 2009, pp. 551-560. doi:10.1093/jxb/erp069

[2] J. M. Morgan and R. W. King, "Association between Loss of Leaf Turgor, Abscisic Acid Levels and Seed Set in Two Wheat Cultivars," Australian Journal of Plant Physiology, Vol. 11, No. 3, 1984, pp. 143-150. doi:10.1071/PP9840143

[3] L. Szabados and A. Savoure, "Proline: A Multifunctional Amino Acid," Trends in Plant Sciences, Vol. 15, No. 2, 2009, pp. 89-97.

[4] M. Ashraf, "Inducing Drought Tolerance in Plants," Biotechnology Advances, Vol. 28, No. 1, 2009, pp. 169-183.

[5] M. Helena and C. D. Carvalho, "Drought Stress and Reactive Oxygen Species," Plant Signalling and Behaviour, Vol. 3, No. 3, 2008, pp. 156-165.

[6] C. Bowler, V. M. Montagu and D. Inzé, "Superoxide Dismutases and Stress Tolerance," Annual Review of Plant Physiology and Plant Molecular Biology, Vol. 43, No. 1, 1992, pp. 83-116.

doi:10.1146/annurev.arplant.43.1.83

[7] G. Govind, H. V. T. Gowda, P. J. Kalaiarasi, D. R. Iyer, S. K. Muthappa, S. Nese and U. K. Makarla, "Identification and Functional Validation of a Unique Set of Drought Induced Genes Preferentially Expressed in Response to Gradual Water Stress in Peanut," Molecular Genetics and Genomics, Vol. 281, No. 6, 2009, pp. 591-605. doi:10.1007/s00438-009-0441-y

[8] I. S. Khairwal, S. K. Yadav, K. N. Rai, H. D. Upadhyaya, D. Kachhawa, B. Nirwan, R. Battacharjee, B. S. Rajpurohit, C. J. Dangaria and Srikant, "Evaluation and Identification of Promising Pearl Millet Germplasm for Grain and Fodder Traits," Journal of SAT Agricultural Research, Vol. 5, No. 1, 2007, pp. 1-6.

[9] B. R. Whan, W. K. Anderson and R. F. Gilmour, "A Role for Physiology in Breeding for Improved Wheat Yield under Drought Stress," In: E. Acevedo, A. P. Conesa, Pmonneveux and J. P. Srivastava, Ed., Physiology-Breeding of Winter Cereals for Stressed Mediterranean Environments, I. N. R. A, les Collogues, Montpellier, 1991, pp. 179-191.

[10] H. D. Barrs and P. E. Weatherly, "A Re-Examination of the Relative Turgidity Technique for Estimating Water Deficits in Leaves," Australian Journal of Biological Science, Vol. 15, No. 3, 1962, pp. 413-428.

[11] P. F. Scholander, H. T. Hammel, E. D. Bradstreet and E. A. Himminosen, "Sap Pressure on Vascular Plants," Science, Vol. 148, No. 3668, 1966, pp. 339-346. doi:10.1104/pp.41.3.529

[12] R. C. Babu, M. S. Pathan, A. Blum and T. N. Nguyen, "Comparison of Measurement Methods of Osmotic Adjustment in Different Rice Cultivars," Crop Science, Vol. 39, No. 1, 1999, pp. 150-158. doi:10.2135/cropsci1999.0011183X003900010024x

[13] N. C. Turner, J. C. Toole, R. T. Cruz, E. B. Yambao, S. Ahmad, O. S. Namuco and M. Dingkuhn, "Response of Seven Diverse Rice Cultivars to Water Deficit. II Osmotic Adjustment, Leaf Elasticity, Leaf Extension, Leaf Death, Stomatal Conductance and Photosynthesis," Field Crops Research, Vol. 13, 1986, pp. 273-286. doi:10.1016/0378-4290(86)90028-6

[14] G. D. Rao, M. Vanaja, K. C. Lakkneni and P. R. Reddy, "Stability of Excised Leaf Water Retention Capacity (ELWRC) Technique for Screening Castor Genotypes," Journal of Oilseed Research, Vol. 15, No. 2, 1998, pp. 280-287.

[15] L. S. Bates, R. P. Waldren and I. D. Teare, "Rapid Determination of Free Proline for Water Stress Studies," Plant Soil, Vol. 39, No. 1, 1973, pp. 205-207. doi:10.1007/BF00018060

[16] M. Dubois, K. Gilles, J. K. Hamilton, P. A. Rebers and F. Smith, "A Colorimetric Method for the Determination of Sugars," Nature, Vol. 168, No. 4265, 1951, pp. 167-168. doi:10.1038/168167a0

[17] H. Rosen, "A Modified Ninhydrin Colorimetric Analysis for Amino Acids," Archives of Biochemistry and Biophysics, Vol. 67, No. 1, 1957, pp. 10-15. doi:10.1016/0003-9861(57)90241-2

[18] J. C. O'Toole and J. G. Real, "Estimation of Aerodynamic and Crop Resistances from Canopy Temperature," Agronomy Journal, Vol. 78, No. 2, 1986, pp. 305-310. doi:10.2134/agronj1986.00021962007800020019x

[19] R. L. Heath and L. Packer, "Photo Peroxidation in Isolated Chloroplasts. I Kinetics and Stoichiometry of Fatty Acid Peroxidation," Archives of Biochemistry and Biophysics, Vol. 125, No. 1, 1968, pp. 189-198. doi:10.1016/0003-9861(68)90654-1

[20] G. S. Premachandra, H. Saneoka, M. Kanaya and S. Ogata, "Cell Membrane Stability and Leaf Surface Wax Content as Affected by Increasing Water Deficits in Maize," Journal of Experimental Botany, Vol. 42, No. 2, 1991, pp. 167-171. doi:10.1093/jxb/42.2.167

[21] R. K. Sairam, "Effect of Moisture Stress on Physiological 
Activities of Two Contrasting Wheat Genotypes," Indian Journal of Experimental Biology, Vol. 32, 1994, pp. 584593.

[22] M. M. Bradford, "A Rapid and Sensitive Method for the Quantitation of Microgram Quantities of Utilizing the Principle of Protein-Dye Binding," Annals of Biochemistry, Vol. 72, No. 1-2, 1976, pp. 248-254. doi:10.1016/0003-2697(76)90527-3

[23] R. S. Dhindsa, P. P. Dhindsa and T. A. Throne, "Leaf Senescence; Correlated with Increased Levels of Membrane Permeability and Lipid Peroxidation and Decreased Levels of Superoxide Dismutase and Catalase," Journal of Experimental Botany, Vol. 32, 1981, pp. 93-101. doi: $10.1093 / \mathrm{jxb} / 32.1 .93$

[24] A. Claiborne, "Catalase Activity," In: R. A. Greenwald, Ed., Handbook of Methods for Oxygen Radical Research, CRC, Boca Raton, 1985, pp. 283-284.

[25] I. K. Smith, T. L. Vierheller and C. A. Thorne, "Assay of Glutathione Reductase in Crude Tissue Homogenates Using 5.5-Dithiobis(2-nitobenzoic acid)," Annals of Biochemistry, Vol. 175, No. 2, 1988, pp. 408-413. doi:10.1016/0003-2697(88)90564-7

[26] Y. Nakano and K. Asada "Hydrogen Peroxide is Scavenged by Ascorbate Specific Peroxides in Spinach Chlooplasts," Plant Cell Physiology, Vol. 22, No. 5, 1981, pp. 867-880.

[27] B. Chance and A. C. Maehly "Assay of Catalase and Peroxidases," Methods in Enzymology, Vol. 2, No. 11, 1955, pp. 764-775. doi:10.1016/S0076-6879(55)02300-8

[28] G. W. Snedecor and W. G. Cochran, "Statistical Methods," Oxford and IBH Publishing Co., Calcutta, 1967.

[29] I. E. Henson,V. Mahalakshmi, F. R. Bidinger and G. Alagarswamy, "Osmotic Adjustment to Water Stress in Pearl Millet (Pennisetum glaucum [L.] Leeke) under Field Conditions," Plant, Cell and Environment, Vol. 5, No. 2, 1982, pp. 147-154. doi:10.1111/1365-3040.ep11571559

[30] N. Thurling and L. D. Das "The Relationship for PreAnthesis Development and Seed Yield of Spring Rape (Brassica napus L.)," Australian Journal of Agricultural Research, Vol. 31, No. 1, 1980, pp. 25-36. doi:10.1071/AR9800025

[31] S. K. Yadav, N. J. Lakshmi, M. Maheswari, M. Vanaja and B. Venkateswarlu, "Influence of Water Deficit at
Vegetative, Anthesis and Grain Filling Stages on Water Relation and Grain Yield in Sorghum," Indian Journal of Plant Physiology, Vol. 10, No. 1, 2005, pp. 20-24.

[32] I. E. Henson, "Osmotic Adjustment to Water Stress in Pearl Millet (Pennisetum glaucum (L.) Leeke) in a Controlled Environment," Journal of Experimental Botany, Vol. 33, No. 1, 1982, pp. 78-87. doi:10.1093/jxb/33.1.78

[33] A. Gonzalez, I. Martin and L. Ayerbe, "Yield and Osmotic Adjustment Capacity of Barley under Terminal Water-Stress Conditions," Journal of Agronomy and Crop Science, Vol. 194, No. 2, 2008, pp. 81-91.

[34] I. Slama, S. Tayachi and A. Jadey, "Differential Response to Water Deficit Stress in Alfalfa (Medicago sativa) Cultivars: Growth, Water Relations, Osmolyte Accumulation and Lipid Peroxidation," Journal of Biotechnology, Vol. 10, No. 72, 2008, pp. 16250-16259.

[35] A. Takele, "Differential Responses of Electrolyte Leakage and Pigment Compositions in Maize and Sorghum after Exposure to and Recovery From Pre- and PostFlowering Dehydration," Agricultural Science of China, Vol. 9, No. 6, 2010, pp. 813-824. doi:10.1016/S1671-2927(09)60159-0

[36] H. E. Patil, M. K. Mahatma, N. J. Patel, R. Bhatnagar and G. C. Jadeja, "Differential Response of Pearl Millet Hybrids to Water Stress in Relation to Antioxidant Enzymes and Proline," Indian Journal of Plant Physiology, Vol. 10, No. 4, 2005, pp. 344-348.

[37] W. Tezara, W. J. Mitchell, S. D. Driscoll and D. W. Lawlor, "Effects of Water Deficit and Its Interaction with $\mathrm{CO}_{2}$ Supply on the Biochemistry and Physiology of Photosynthesis in Sunflower," Journal of Experimental Botany, Vol. 53, No. 375, 2002, pp. 1781-1791. doi:10.1093/jxb/erf021

[38] R. Khanna-Chopra and M. Maheswari, "Effect of Altering Source Availability on Expression of Sink Capacity in a Maize Hybrid and Its Parents," European Journal of Agronomy, Vol. 9, No. 1998, pp. 101-107. doi:10.1016/S1161-0301(98)00028-8

[39] A. Hussain, M. R. Chaudhry, A. Wajid, A. Ahmad, M. Rafiq, M. Ibrahim and A. R. Goheer, "Growth, Yield and Radiation Use Efficiency of Various Wheat Cultivars," International Journal of Agricultural Science, Vol. 6, No. 6, 2004, pp. 1074-1079.

TSS: Total soluble sugars,

FAA: Free amino acids,

MDA: Malondialdehyde,

MSI: Membrane stability index,

AOX: Antioxidative enzymes,

SOD: Superoxide dismutase,

CAT: Catalase,

GR: Glutathione reductase,

APX: Ascorbate peroxidase,

GPOX: Guaiacol peroxidase,

TB: Total biomass. 